Tkachenko T.I.,

Dr. of Science (Economics), Professor, Head of the Dpt. of Tourism and Recreation

Google Scholar: https://scholar.google.com.ua/citations?user=JijfQg8AAAAJ\&hl=uk Hladkyi O.V., Dr. of Science (Geography), Professor, The Dpt. of Tourism and Recreation Kyiv National University of Trade and Economics

\title{
BASIC CONDITIONS OF RESORT TERRITORY DEVELOPMENT MANAGEMENT
}

Resort is a developed natural area on the lands of recreational category with medicinal resources, buildings with the objects of infrastructure used for treatment, medical rehabilitation, prevention of diseases and recreation being subject to special protection. Recreation territory is a natural area with mineral and thermal waters, medicinal mud, ozokerite, brine of coastal salt lakes, climatic and other conditions. Each resort territory has its own characteristics, but there are four common ones.

1. Resort territory is a collection of the following components: a resort resources (natural wealth or man-made, that is what encourages a recreant to rest); convenience (accommodation, food, entertainment, as well as retail and other services businesses, such as banks, exchange offices, hairdressers, medical enterprises, that is all that not only provides shelter and food, but also creates a general feeling of hospitable reception of recreants by this territory); accessibility (the distance of the resort territory from resort markets makes them vulnerable to declining demand, since it is possible to reach such resort territory only by long vacation. Therefore, the development and maintenance of efficient transport links with resort markets is essential for the success of the resort territory. But for recreants it is important not only physical accessibility, external transport links with it, but also the existence of developed internal transport links. In other words, services such as car rental, local transport and transfers to resort territories); support services that provide services such as resort territory advertising, coordination and management of its development, provision of necessary information and services to the population and organizations for reservation, provision with equipment 
(catering, sports, etc.), provision of resort territory by the management personnel.

2. Resort territory is a cultural value: visitors should consider the resort territory resources and deserving of the time and money spent on recreation. Thus, it is important to keep the conditions of the resort territory different from the usual «home» conditions with the help of good design and management to avoid the development of a «unified resort landscape».

3. Resort territory is inseparable. A resort product is consumed where it is directly produced, and recreants must be physically present on the resort territory in order to experience it. It should be noted that the processes of production and consumption of a resort product coincide not only in space, but also in time, i.e. Resort territories cannot be stored for future use (hotel rooms, medical treatment, etc. cannot be postponed to the «off-season» for their subsequent sale). Thus, seasonality of resort territory is the most important problem, as it reduces their profitability and makes them ineffective from the point of view of using the main means of resort territory. For seasonal resort territories, peak season (3 4 months) should bring the main contribution to covering fixed costs that are payable during the year.

4. Not only recreants but also other people use the services and amenities of the resort territory: local residents and employees of this resort territory. Thus, the enterprises of resort territory cannot be oriented only to local residents or only to recreants, they should be guided by those and others.

A key condition for the successful development of resort territory of any rank, bearing in mind their significant determinism by the factors of the internal and external environment, is the adherence to global trends, reasonable borrowing of positive service practices and constructive national-state policy.

At the heart of the resort territories competitiveness management system is a quality resort product, which is the main objective of the resort territory competitiveness management system functioning, and all managerial decisions should be evaluated from the point of view of their influence on this indicator. 